\title{
Genotoxic effects of anesthetics in operating room personnel evaluated by micronucleus test
}

Tânia Kawasaki de Araujo', Roseane Lopes da Silva-Grecco', Flora Margarida Barra Bisinotto², Nilson Camargos Roso², Cristina Wide Pissetti ${ }^{1}$, Ricardo Manoel da Cruz ${ }^{1}$ and Marly Aparecida Spadotto Balarin ${ }^{1 *}$

*Correspondence: balarin@mednet.com.br

'Genetic Department, Institute of Biological and Natural Sciences, Federal University of the Triângulo Mineiro (UFTM), Uberaba, Minas Gerais, Brazil.

${ }^{2}$ Anesthesiology Department, Institute of Health Science, Federal University of Triângulo Mineiro (UFTM), Uberaba, Minas Gerais, Brazil.

\begin{abstract}
Exposure to certain chemical agents causes damage to the genetic material. There is controversy about the genotoxic and/or mutagenic effect caused by acute or chronic anesthetics exposure. The aim of this research was to assess and compare the frequency of micronuclei (MN) in professionals working in operating rooms and other hospital areas. The genotoxic and cytotoxic effects were evaluated in lymphocytes using the micronucleus test and the proliferative index, respectively. We examined peripheral blood lymphocyte cultures from 30 operating room professionals (exposed group) and 30 professionals non-exposed in other hospital areas of the same hospital (control group). There was no statistically significant difference in proliferative index between the groups. Nevertheless, there was an increase in MN frequency in binucleated (BN) cells in the exposed group $(p=0.0003)$ compared to the control group. Moreover, there was a statistically significant difference between genders ( $\mathrm{p}=0.0187)$, and the frequency of $\mathrm{MN}$ in BN cells from women was higher than in men. Therefore, gender influenced the frequency of MN. The age and period of working time in an operating room influenced the MN frequency only in women professionals. Thereby, there was a genotoxic effect in occupationally exposed professionals, and the micronucleus test could be used in the biomonitoring of human populations for evaluating the risk of developing cancer.
\end{abstract}

Keywords: Anesthetics, micronuclei test, genotoxic, occupational exposure

\section{Introduction}

Volatile anesthetics are the major pollutants in operating rooms, where the professionals are exposed to low doses of them, for long periods of time. Neurotoxic [32], hepatotoxic [22], nephrotoxic [24,32] and carcinogenic effects [13,32,39], as well as fertility alterations, increased incidence of spontaneous abortions and congenital abnormalities have been observed

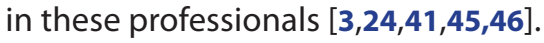

Nevertheless, there is still some controversy regarding the genotoxic and/or mutagenic effects of acute or chronic exposure to anesthetic gases $[14,25,27]$, even though significant increases in the frequency of chromosome aberrations and of micronuclei (MN) in peripheral blood lymphocytes of professionals exposed to such agents have been reported $[8,11,12,29,31,35,42,44]$.

The micronucleus test is a method for the assessment of several kinds of cytogenetic damages, used in the biomonitoring of human populations for evaluating the risk of developing cancer and identifying the genotoxic potential of chemical, physical and biological agents $[1,31,35,42]$.

Originally, the micronucleus test focused exclusively on the binucleated (BN) cells [16]. However, it was observed that MN in mononucleated (MO) cells, as well as proliferative index (PI), could provide complementary information, since these data may indicate damage that is present in vivo, before cell culture is set up, which makes them interesting for the purpose of biomonitoring $[\mathbf{2 8 , 4 0 ]}$.
Information about possible genetic damage in professionals following exposure to waste anesthetic gases in operating rooms in Brazil is scant. Therefore, the objective of the present study was to verify the frequency of $M N$ in professionals who were occupationally exposed to anesthetic gases in operating rooms and compare with professionals non-exposed in other hospital areas of the same hospital.

\section{Material and methods Population study}

Participation in the study took place after the signing of a Free and Informed Consent Form. The study was conducted following the approval of the Research Ethics Committee of the Federal University of the Triângulo Mineiro (CEP/UFTM - no 962). The sample was composed of 60 professionals who worked at the Clinics's Hospital/UFTM, located at Uberaba, State of Minas Gerais, Brazil and were recruited between the years 2007 and 2008. They were divided into two groups: exposed group, comprising 30 professionals who worked in operating rooms; and control group, comprising another 30 professionals, who did not work in operating rooms. The groups were matched for age and gender. Table 1 shows the main characteristics of both groups.

Each individual was interviewed using a standard questionnaire with questions regarding age, gender, use of medications, medical treatments, life style (consumption of cigarettes and 
Araujo et al. Journal of Anesthesiology and Clinical Science 2013,

http://www.hoajonline.com/journals/pdf/2049-9752-2-26.pdf

doi: 10.7243/2049-9752-2-26

Table 1. Demographic characteristics of study population.

\begin{tabular}{lll}
\hline & Control & Exposed \\
\hline Sex n \\
$\quad$ Male & & \\
Female & $14(46.7)$ & $14(46.7)$ \\
\hline Age & $16(53.3)$ & $16(53.3)$ \\
$\quad$ Male & & \\
$\quad$ Mean \pm SD & $40.50 \pm 12.06$ & $40.28 \pm 11.06$ \\
$\quad$ Range & $28-61$ & $26-60$ \\
Female & & \\
$\quad$ Mean $\pm S D$ & $41.50 \pm 11.63$ & $41.75 \pm 11.83$ \\
$\quad$ Range & $23-61$ & $25-60$ \\
\hline Years of Experience & & \\
$\quad$ Mean $\pm S D$ & -- & $13.83 \pm 10.93$ \\
$\quad$ Range & -- & $2-37$ \\
\hline & & \\
\hline
\end{tabular}

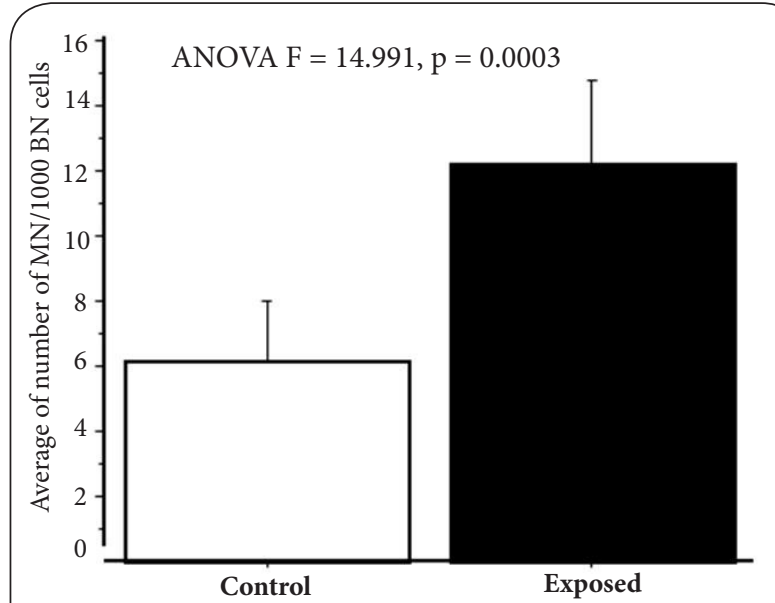

Figure 1. Comparison of the number of $\mathrm{MN}$ in $1000 \mathrm{BN}$ cells between exposed and control groups.

alcohol), and occupational questions (time in the profession, daily working hours, exposure to X-rays). The selected professionals had been working at the hospital for at least two year. The professionals who worked in operating rooms spent $10 \mathrm{~h} /$ day in the operation room and worked for 6 days/ week. During their service as operating room personnel, all subjects were exposed to a complex mixture of anesthetic agents (halothane, enflurane, isoflurane, sevoflurane, nitrous oxide among others). It was assured that the operating room personnel and the controls did not statistically differ from each other except for occupational exposure. Professionals who had undergone medical treatment of any kind, had any infectious disease or worked in a service with exposure to $X$-rays were excluded of sample.

A code number was assigned to each individual sample and its corresponding slides for culture identification and identity preservation.

\section{Micronucleus test}

Samples of whole blood were drawn from all subjects, and conventional short-term lymphocyte cultures were made.
Cultures were set up by adding $0.5 \mathrm{ml}$ whole blood to 4.5 $\mathrm{ml}$ of RPMI medium with 20\% fetal calf serum (Gibco ${ }^{\hat{a}}$ ) and antibiotics (penicillin and streptomycin). Lymphocytes were stimulated with $0.18 \mathrm{mg} / \mathrm{ml}$ phytohemagglutinin (Sigma ${ }^{\hat{a}}$ ) and incubated at $37^{\circ} \mathrm{C}$ for $72 \mathrm{~h}$. Cytochalasin B (Sigma $a^{a}$ ) at a final concentration of $6 \mu \mathrm{l} / \mathrm{ml}$ was added at $44 \mathrm{~h}$ of incubation. The cultures were harvested and the cells were submitted to a mild hypotonic treatment and then fixed with methanol:acetic acid (3:1). Microscope slides were prepared and, after the cells dried, the slides were stained with $4 \%$ Giemsa for 5 minutes. The slides were coded at the time of preparation and scoring. The frequency of MN was determined in 2000

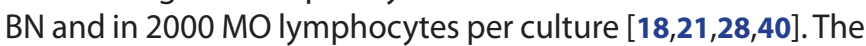
slides were analyzed using a Carl Zeiss ${ }^{a}$ microscope with an X400 objective. Scoring criteria for selection of BN cells and $\mathrm{MN}$ were set according to the criteria of Fenech and Morley [16]. The slides were decoded before statistical analysis for comparison. As a parameter for cytotoxicity, nuclear division index (NDI) was calculated according to the formula: $\mathrm{NDI}=$ $(M 1+2 M 2+3 M 3+4 M 4) / N$, where $M 1-M 4$ represent the number of cells with 1-4 nuclei and $\mathrm{N}$ is the total number of viable cells scored (excluding necrotic and apoptotic cells) [21].

\section{Statistical analysis}

Statistical analysis was performed using the StatView 6.0 software. The level of significance was set at $p<0.05$. Normality of the data was determined by means of the Kolmogorov-Smirnov test. Multifactorial variance analysis (ANOVA- FACTORIAL) was made for gender and condition (control or exposed) and micronuclei frequency. Student's t-test and Fisher's PLSD test were employed for analyzing the correlation between exposure time and frequency, and between age and MN frequency, and descriptive statistics was performed. We could not estimate the interaction between time of exposure and age.

\section{Results}

As mentioned above, the sample was composed of 32 women (53.3\%) and 28 men (46.7\%) professionals, 30 of which worked in operating rooms (exposed) and 30 of which worked in other hospital areas, matched for gender and age.

With regard to the NDI, the mean and standard deviation in the exposed and control group were $1.68 \pm 0.25$ and $1.69 \pm 0.21$, respectively $(p=0.9681)$. This data indicated that occupational exposure to the anesthetic gases did not have toxic effects on lymphocytes impairing their mitotic proliferation in vitro. Considering the total sample, a statistically significant increase of MN frequency was observed only in the BN cells $(p=0.0003)$ of the exposed group compared with control group (Figure 1). MN frequency in BN cells was increased in women $(p=0.0203)$ as well as in men $(p=0.0001)$ compared with the respective control group. On the other hand, an increased MN frequency in $\mathrm{MO}$ cells was found only in males ( $p=0.0035)$ (Table 2 ).

Only in the control group, the women showed statistically 
Araujo et al. Journal of Anesthesiology and Clinical Science 2013, http://www.hoajonline.com/journals/pdf/2049-9752-2-26.pdf

Table 2. Descriptive measures of the number of $\mathrm{MN}$ $\left(\mathrm{MN} \mathrm{n}^{\circ} / 1000 \mathrm{BN}\right.$ cells and $\mathrm{MN} \mathrm{n} / 1000 \mathrm{MO}$ cells) in the control and exposed groups by gender and result of ANOVA test.

\begin{tabular}{lcccccc}
\hline \multicolumn{6}{c}{ Groups } \\
\hline Gender & Type of cells & $\mathbf{n}$ & Mean \pm SD & $\mathbf{n}$ & Mean \pm SD & p \\
\hline \multirow{2}{*}{ Female } & BN cells & 16 & $14.28 \pm 8.32$ & 16 & $8.16 \pm 5.54$ & $0.0203^{*}$ \\
& MO cells & 16 & $2.84 \pm 2.54$ & 16 & $2.91 \pm 3.06$ & 0.9503 \\
\hline \multirow{2}{*}{ Male } & BN cells & 14 & $9.68 \pm 3.83$ & 14 & $3.79 \pm 2.91$ & $0.0001^{*}$ \\
& MO cells & 14 & $3.57 \pm 2.98$ & 14 & $0.86 \pm 1.06$ & $0.0035^{*}$ \\
\hline
\end{tabular}

${ }^{*}$ significant difference $(\mathrm{p}<0.05)$, mean $\pm \mathrm{SD}=$ mean \pm standard deviation, $\mathrm{n}=$ number of individuals.

Table 3. Descriptive measures of the number of $\mathrm{MN}$ (MN No/1000 BN cells) in the control and exposed groups between gender and result of ANOVA test.

\begin{tabular}{lcccc}
\hline \multicolumn{5}{c}{ Groups } \\
\hline Parameter & $\mathbf{n}$ & Mean \pm SD & n & Mean \pm SD \\
\hline Gender & & & & \\
Female & 16 & $14.28 \pm 8.33$ & 16 & $8.16 \pm 5.54$ \\
Male & 14 & $9.68 \pm 3.83$ & 14 & $3.79 \pm 2.91$ \\
& & $\mathrm{p}=0.0681$ & & $\mathrm{p}=0.0132^{\star}$ \\
& & $\mathrm{F}=3.600$ & & $\mathrm{~F}=7.010$ \\
\hline
\end{tabular}

*significant difference $(\mathrm{p}<0.05)$, mean $\pm \mathrm{SD}=$ mean \pm standard deviation, $\mathrm{n}=$ number of individuals.

Table 4. Descriptive measures of the number of MN (MN $\mathrm{No} / 1000 \mathrm{MO}$ cells) in the control and exposed groups between gender and result of ANOVA test.

\begin{tabular}{lcccc}
\hline \multicolumn{5}{c}{ Exposed } \\
\hline Parameter & n & Mean \pm SD & n & Mean \pm SD \\
\hline Gender & & & & \\
Female & 16 & $2.84 \pm 2.55$ & 16 & $2.91 \pm 3.06$ \\
Male & 14 & $3.57 \pm 2.98$ & 14 & $0.86 \pm 1.06$ \\
& & $\mathrm{p}=0.4767$ & & $\mathrm{p}=0.0243^{*}$ \\
& & $\mathrm{~F}=0.520$ & & $\mathrm{~F}=5.670$ \\
\hline
\end{tabular}

* significant difference $(\mathrm{p}<0.05)$, mean $\pm \mathrm{SD}=$ mean \pm standard deviation, $\mathrm{n}=$ number of individuals.

significant increase of MN frequency in BN cells ( $p=0.0132)$ as well as in MO cells ( $p=0.0243$ ) compared to men (Table 3 and 4 respectively).

To analyze the effect of age in exposed and control groups, they were divided into two subgroups. One of 25-44 years of age was composed of 16 individuals ( 8 men and 8 women) and the other with 45-64 years of age was composed of 14 individuals ( 6 men and 8 women).

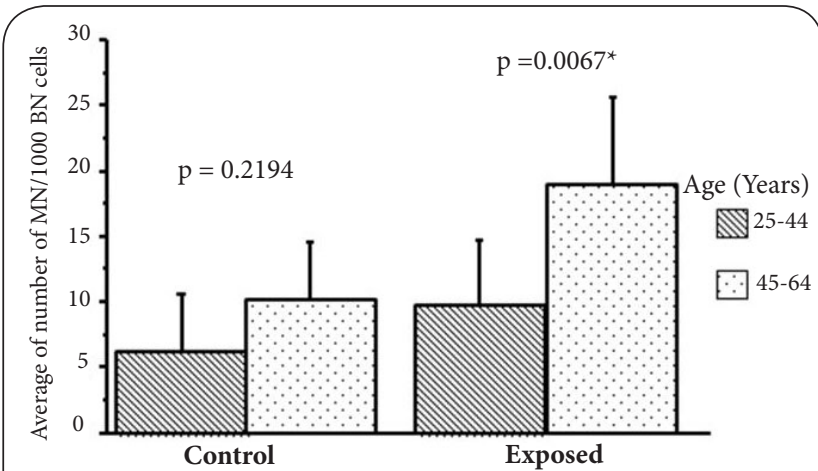

Figure 2. Comparison of the average number of $\mathrm{MN}$ in $\mathrm{BN}$ cells by age in females.

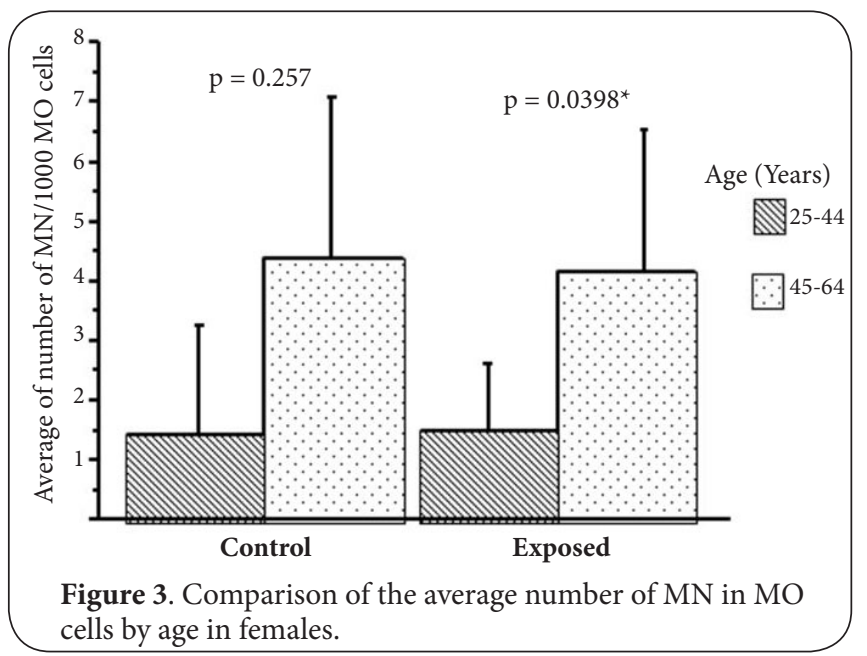

Performing the analysis separating by age and gender, a statistically significant increase in $\mathrm{MN}$ frequency of BN cells $(p=0.0067)$ and MO cells $(p=0.0398)$ was observed with growing age only in women of the exposed group (Figures 2 and 3 respectively).

The incidence of $\mathrm{MN}$ in $\mathrm{MO}$ and $\mathrm{BN}$ cells (Figure 4) increased with time of exposure to anesthetics only in women.

\section{Discussion}

Among the most promising prevention strategies are the use and validation of biomarkers, which can anticipate the clinical diagnosis and steer measures of prevention in populations under risk, resulting from exposure to carcinogens or to a genetic susceptibility $[26,34]$.

The use of MN as biomarkers is based on the fact that cancer cells present cytogenetic abnormalities, which reinforces the hypothesis that chromosomal damages are directly involved in cancer etiology [50].

Several factors can influence the frequency of $\mathrm{MN}$ in the cell, such as age $[2,16,19,33,36,47]$, gender $[5,6,20,19]$, vitamins, medical treatment, daily exposure to genotoxic agents, among others $[\mathbf{7 , 2 0}]$. 


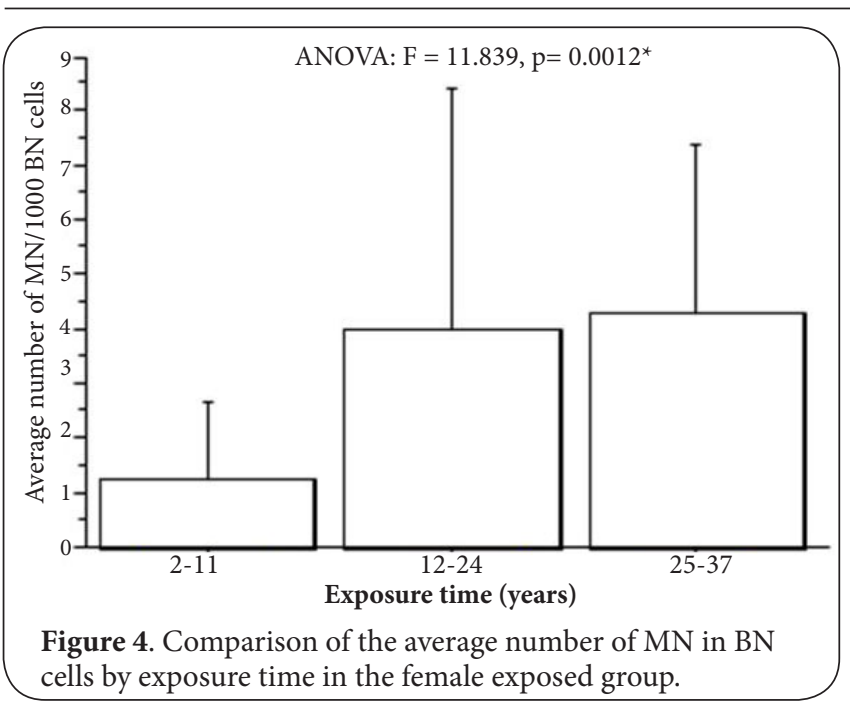

The increase in $\mathrm{MN}$ frequency indicates defects in DNA repair and in chromosome segregation, which might result in the generation of daughter cells with an altered gene dosage and/or dysregulated gene expression, thus leading to a chromosomal instability phenotype, as observed in cancers $[9,15,18,34]$. The study of Leach and Jackson-Cook [2001] [30] showed that any chromosome could be present in MN.

The mechanism by which the anesthetics induce DNA damage is still controversial. In the present study, we observed a significant increase in $\mathrm{MN}$ frequency in the exposed group, in both genders. There are previous reports in the literature showing a significant increase in MN frequency in exposed women $[31,37,43]$. In our study, however, we also found a difference in the man professionals.

In this study, the women showed statistically significant increase of MN frequency when compared to men. Could not be determined the reason for the high frequency of $M N$ in women, but one hypothesis is the loss of chromosome $X$, which is prone to suffer spontaneous as well as induced malsegregation, especially in elder women $[17,23]$.

Data from the literature showed that the increase in MN frequency in BN cells with age was observed in both genders. $[4,6,10,16,17,19,38,51]$. However, in the present study, we found an increase only in the exposed women, probably because the number of individuals in our sample was too small to separate them by age bracket.

The relationship of age with a decline in the efficiency of the DNA repair processes and the accumulation of mutations due to adverse endogenous and exogenous conditions results in an increasing level of DNA damage, reflected on the cytogenetic level by an increase in the frequency of chromosome aberrations $[4,38,48,51]$ and $M N$ in the peripheral blood lymphocytes of elderly individuals $[6,7,16,17]$.

Bukvic et al., (2001) [10] showed an increase in MN frequency in older individuals, and this was observed more frequently in females. Several studies have shown an association between chronological age and aneuploidy, and the most frequent loss of the $X$ and $Y$ chromosomes in females and males respectively $[4,5,38]$.

The result of our study indicates the danger of exposure to anesthetic gases in exposed workers, suggesting the need to reduce the period of exposure. The anesthetic gases scavenger and air conditioning equipment should be used and sufficient ventilation should be supplied. Furthermore, preventive health examination of all exposed workers should be periodically performed.

Although the chromosome aberration analysis is more sensitive, it requires time and highly skilled professionals, which makes the biomonitoring of large groups of workers difficult. Therefore, MN analysis in human lymphocytes using the cytochalasin B technique [16] has been proposed as a valid and less laborious alternative for large-scale studies [15].

Since chromosome instability can occur by chromosome loss or break and the evaluation of micronuclei furnishes a measurement of both chromosome losses and breaks, it therefore plays an important role as a biomarker for cancer risk. Thus, the micronucleus test could be used in the planning, implementation and validation of cancer vigilance and prevention policies for professionals who are occupationally exposed to anesthetics.

\section{Competing interests}

The authors declare that they have no competing interests.

\section{Authors' contributions}

$M B$ and RLS substantially contributed to the conception and design. TKA, RLS, CWP, RMC, FBB, NCR and MB acquisited and interpreted the data. TKA, RLS, FBB, NCR, CWP and $M B$ drafted the article or revised it critically for important intellectual content. TKA, RLS, FBB, NCR, CWP, RMC and MB finally approved the version to be published.

\section{Acknowledgement}

We would like to thank the volunteers for their helpful cooperation. This work was supported by the FAPEMIG and FUNEPU.

\section{Publication history}

Received: 07-Feb-2013 Revised: 13-Mar-2013

Re-Revised: 12-May-2013 Accepted: 06-Jun-2013

Published: 03-Aug-2013

\section{References}

1. Albertini RJ, Anderson D, Douglas GR, Hagmar L, Hemminki K, Merlo F, Natarajan AT, Norppa H, Shuker DE, Tice R, Waters MD and Aitio A. IPCS guidelines for the monitoring of genotoxic effects of carcinogens in humans. International Programme on Chemical Safety. Mutat Res. 2000; 463:111-72. | Article | PubMed

2. Au WW, Walker DM, Ward JB, Jr., Whorton E, Legator MS and Singh V. Factors contributing to chromosome damage in lymphocytes of cigarette smokers. Mutat Res. 1991; 260:137-44. I Article I PubMed

3. Baden JM, Brinkenhoff M, Wharton RS, Hitt BA, Simmon VF and Mazze RI. Mutagenicity of volatile anesthetics: halothane. Anesthesiology. 1976; 45:311-8. | Article | PubMed

4. Bohr VA. DNA repair fine structure and its relations to genomic 
Araujo et al. Journal of Anesthesiology and Clinical Science 2013, http://www.hoajonline.com/journals/pdf/2049-9752-2-26.pdf

instability. Carcinogenesis. 1995; 16:2885-92. | Article | PubMed

5. Bolognesi C, Abbondandolo A, Barale R, Casalone R, Dalpra L, De Ferrari $M$, Degrassi F, Forni A, Lamberti L, Lando C, Migliore L, Padovani P, Pasquini R, Puntoni R, Sbrana I, Stella M and Bonassi S. Age-related increase of baseline frequencies of sister chromatid exchanges, chromosome aberrations, and micronuclei in human lymphocytes. Cancer Epidemiol Biomarkers Prev. 1997; 6:249-56. | Article | PubMed

6. Bolognesi C, Lando C, Forni A, Landini E, Scarpato R, Migliore L and Bonassi S. Chromosomal damage and ageing: effect on micronuclei frequency in peripheral blood lymphocytes. Age Ageing. 1999; 28:3937. | Article | PubMed

7. Bonassi S, Fenech M, Lando C, Lin YP, Ceppi M, Chang WP, Holland N, Kirsch-Volders M, Zeiger E, Ban S, Barale R, Bigatti MP, Bolognesi C, Jia C, Di Giorgio M, Ferguson LR, Fucic A, Lima OG, Hrelia P, Krishnaja AP, Lee TK, Migliore L, Mikhalevich L, Mirkova E, Mosesso P, Muller WU, Odagiri Y, Scarffi MR, Szabova E, Vorobtsova I, Vral A and Zijno A. HUman MicroNucleus project: international database comparison for results with the cytokinesis-block micronucleus assay in human lymphocytes: I. Effect of laboratory protocol, scoring criteria, and host factors on the frequency of micronuclei. Environ Mol Mutagen. 2001; 37:31-45. Article I PubMed

8. Bonassi S, Forni A, Bigatti P, Canevarollo N, De Ferrari M, Lando C, Padovani P, Bevegni M, Stella M, Vecchio D and Puntoni R. Chromosome aberrations in hospital workers: evidence from surveillance studies in Italy (1963-1993). Am J Ind Med. 1997; 31:353-60. | Article | PubMed

9. Bonassi S, Znaor A, Ceppi M, Lando C, Chang WP, Holland N, KirschVolders M, Zeiger E, Ban S, Barale R, Bigatti MP, Bolognesi C, CebulskaWasilewska A, Fabianova E, Fucic A, Hagmar L, Joksic G, Martelli A, Migliore L, Mirkova E, Scarfi MR, Zijno A, Norppa H and Fenech M. An increased micronucleus frequency in peripheral blood lymphocytes predicts the risk of cancer in humans. Carcinogenesis. 2007; 28:625-31. | Article | PubMed

10. Bukvic N, Gentile M, Susca F, Fanelli M, Serio G, Buonadonna L, Capurso A and Guanti G. Sex chromosome loss, micronuclei, sister chromatid exchange and aging: a study including $\mathbf{1 6}$ centenarians. Mutat Res. 2001; 498:159-67. | Article | PubMed

11. Chang WP, Lee S, Tu J and Hseu S. Increased micronucleus formation in nurses with occupational nitrous oxide exposure in operating theaters Environ Mol Mutagen. 1996; 27:93-7 | Article | PubMed

12. Chandrasekhar M, Rekhadevi PV, Sailaja N, Rahman MF, Reddy JP, Mahboob $\mathrm{M}$ and Grover P. Evaluation of genetic damage in operating room personnel exposed to anaesthetic gases. Mutagenesis. 2006; 21:249-54. | Article | PubMed

13. Corbett TH, Cornell RG, Lieding K and Endres JL. Incidence of cancer among Michigan nurse-anesthetists. Anesthesiology. 1973; 38:260-3. | Article | PubMed

14. Eroglu A, Celep F and Erciyes N. A comparison of sister chromatid exchanges in lymphocytes of anesthesiologists to nonanesthesiologists in the same hospital. Anesth Analg. 2006; 102:1573-7. | Article | PubMed

15. Fenech M, Holland N, Chang WP, Zeiger E and Bonassi S. The HUman MicroNucleus Project--An international collaborative study on the use of the micronucleus technique for measuring DNA damage in humans. Mutat Res. 1999; 428:271-83. | Article | PubMed

16. Fenech $M$ and Morley $A A$. Measurement of micronuclei in lymphocytes. Mutat Res. 1985; 147:29-36. | Article | PubMed

17. Fenech $M$, Neville $S$ and Rinaldi J. Sex is an important variable affecting spontaneous micronucleus frequency in cytokinesis-blocked lymphocytes. Mutat Res. 1994; 313:203-7. | Article | PubMed

18. Fenech M. Chromosomal biomarkers of genomic instability relevant to cancer. Drug Discov Today. 2002; 7:1128-37. | Article | PubMed

19. Fenech M. Chromosomal damage rate, aging, and diet. Ann N Y Acad Sci. 1998; 854:23-36. | Article | PubMed

20. Fenech $\mathrm{M}$. The cytokinesis-block micronucleus technique: a detailed description of the method and its application to genotoxicity studies in human populations. Mutat Res. 1993; 285:35-44. | Article | PubMed

21. Fenech M. Cytokinesis-block micronucleus cytome assay. Nat Protoc.
2007; 2:1084-104. | Article | PubMed

22. Franco G, Marraccini P, Santagostino G, Filisetti P and Preseglio I. Behaviour of urinary D-glucaric acid excretion in surgical patients and anaesthesiology staff acutely exposed to isoflurane and nitrous oxide. Med Lav. 1991; 82:527-32. | PubMed

23. Galloway SM and Buckton KE. Aneuploidy and ageing: chromosome studies on a random sample of the population using G-banding. Cytogenet Cell Genet. 1978; 20:78-95. | Article | PubMed

24. Guirguis SS, Pelmear PL, Roy ML and Wong L. Health effects associated with exposure to anaesthetic gases in Ontario hospital personnel. $\mathrm{Br} J$ Ind Med. 1990; 47:490-7. | Article | PubMed Abstract | PubMed Full Text

25. Hoerauf KH, Wiesner G, Schroegendorfer KF, Jobst BP, Spacek A, Harth $M$, Sator-Katzenschlager $S$ and Rudiger HW. Waste anaesthetic gases induce sister chromatid exchanges in lymphocytes of operating room personnel. Br J Anaesth. 1999; 82:764-6. | Article | PubMed

26. Iarmarcovai G, Bonassi S, Sari-Minodier I, Baciuchka-Palmaro M, Botta A and Orsiere T. Exposure to genotoxic agents, host factors, and lifestyle influence the number of centromeric signals in micronuclei: a pooled re-analysis. Mutat Res. 2007; 615:18-27. | Article | PubMed

27. Jaloszynski P, Kujawski M, Wasowicz M, Szulc R and Szyfter K. Genotoxicity of inhalation anesthetics halothane and isoflurane in human lymphocytes studied in vitro using the comet assay. Mutat Res. 1999; 439:199-206. | Article | PubMed

28. Kirsch-Volders $M$ and Fenech M. Inclusion of micronuclei in non-divided mononuclear lymphocytes and necrosis/apoptosis may provide a more comprehensive cytokinesis block micronucleus assay for biomonitoring purposes. Mutagenesis. 2001; 16:51-8. | Article | PubMed

29. Lamberti L, Bigatti $P$, Ardito $G$ and Armellino F. Chromosome analysis in operating room personnel. Mutagenesis. 1989; 4:95-7. | Article | PubMed

30. Leach NT and Jackson-Cook C. The application of spectral karyotyping (SKY) and fluorescent in situ hybridization (FISH) technology to determine the chromosomal content(s) of micronuclei. Mutat Res. 2001; 495:11-9. | Article | PubMed

31. Lewinska D, Stepnik M, Krajewski W, Arkusz J, Stanczyk M and WronskaNofer T. Increased incidence of micronuclei assessed with the micronucleus assay and the fluorescence in situ hybridization (FISH) technique in peripheral blood lymphocytes of nurses exposed to nitrous oxide. Mutat Res. 2005; 581:1-9. | Article | PubMed

32. Lucchini R, Placidi D, Toffoletto F and Alessio L. Neurotoxicity in operating room personnel working with gaseous and nongaseous anesthesia. Int Arch Occup Environ Health. 1996; 68:188-92. | Article | PubMed

33. Migliore L, Guidotti P, Favre C, Nardi M, Sessa MR and Brunori E. Micronuclei in lymphocytes of young patients under antileukemic therapy. Mutat Res. 1991; 263:243-8. | Article | PubMed

34. Murgia E, Ballardin M, Bonassi S, Rossi AM and Barale R. Validation of micronuclei frequency in peripheral blood lymphocytes as early cancer risk biomarker in a nested case-control study. Mutat Res. 2008; 639:2734. | Article | PubMed

35. Natarajan D and Santhiya ST. Cytogenetic damage in operation theatre personnel. Anaesthesia. 1990; 45:574-7. | Article | PubMed

36. A Nordic data base on somatic chromosome damage in humans. Nordic Study Group on the Health Risk of Chromosome Damage. Mutat Res. 1990; 241:325-37. | Article | PubMed

37. Pasquini R, Scassellati-Sforzolini G, Fatigoni C, Marcarelli M, Monarca $S$, Donato F, Cencetti $S$ and Cerami FM. Sister chromatid exchanges and micronuclei in lymphocytes of operating room personnel occupationally exposed to enfluorane and nitrous oxide. J Environ Pathol Toxicol Oncol. 2001; 20:119-26. | Article | PubMed

38. Ramsey MJ, Moore DH, 2nd, Briner JF, Lee DA, Olsen L, Senft JR and Tucker JD. The effects of age and lifestyle factors on the accumulation of cytogenetic damage as measured by chromosome painting. Mutat Res. 1995; 338:95-106. | Article | PubMed

39. Robbiano L, Mereto E, Migliazzi Morando A, Pastore P and Brambilla G. Increased frequency of micronucleated kidney cells in rats exposed to halogenated anaesthetics. Mutat Res. 1998; 413:1-6. | Article | PubMed 
Araujo et al. Journal of Anesthesiology and Clinical Science 2013, http://www.hoajonline.com/journals/pdf/2049-9752-2-26.pdf

40. Rosefort C, Fauth E and Zankl H. Micronuclei induced by aneugens and clastogens in mononucleate and binucleate cells using the cytokinesis block assay. Mutagenesis. 2004; 19:277-84. I Article I PubMed

41. Rowland AS, Baird DD, Shore DL, Weinberg CR, Savitz DA and Wilcox AJ. Nitrous oxide and spontaneous abortion in female dental assistants. Am J Epidemiol. 1995; 141:531-8. | Article | PubMed

42. Rozgaj R, Kasuba V and Peric M. Chromosome aberrations in operating room personnel. Am J Ind Med. 1999; 35:642-6. | Article I PubMed

43. Rozgaj R, Kasuba V and Jazbec A. Preliminary study of cytogenetic damage in personnel exposed to anesthetic gases. Mutagenesis. 2001; 16:139-43. | Article | PubMed

44. Rozgaj R, Kasuba V, Brozovic G and Jazbec A. Genotoxic effects of anaesthetics in operating theatre personnel evaluated by the comet assay and micronucleus test. Int J Hyg Environ Health. 2009; 212:11-7. | Article I PubMed

45. Talamanca FI. 2000. Reproductive problems among women health care workers: Epidemiologic evidence and preventive strategies. Epidemiol Rev 22:249-260. | Pdf

46. Tannenbaum TN and Goldberg RJ. Exposure to anesthetic gases and reproductive outcome. A review of the epidemiologic literature. $J$ Occup Med. 1985; 27:659-68. | Pdf | PubMed

47. Tomanin R, Ballarin C, Nardini B, Mastrangelo G and Sarto F. Influence of smoking habit on the frequency of micronuclei in human lymphocytes by the cytokinesis block method. Mutagenesis. 1991; 6:123-6. | Article I PubMed.

48. Tucker JD and Preston RJ. Chromosome aberrations, micronuclei, aneuploidy, sister chromatid exchanges, and cancer risk assessment. Mutat Res. 1996; 365:147-59. | Article | PubMed

49. Walker J. What is new with inhaled anesthetics: part I. J Perianest Nurs. 1996; 11:330-333. I Article

50. Weirich-Schwaiger H, Weirich HG, Gruber B, Schweiger M and HirschKauffmann M. Correlation between senescence and DNA repair in cells from young and old individuals and in premature aging syndromes. Mutat Res. 1994; 316:37-48. | Article | PubMed

51. Wojda A, Zietkiewicz E, Mossakowska M, Pawlowski W, Skrzypczak K and Witt M. Correlation between the level of cytogenetic aberrations in cultured human lymphocytes and the age and gender of donors. $J$ Gerontol A Biol Sci Med Sci. 2006; 61:763-72. | Article I PubMed

\section{Citation:}

Araujo T K, da Silva-Grecco R L, Bisinotto F M, Roso N C, Pissetti C W, da Cruz R M and Balarin M A.

Genotoxic effects of anesthetics in operating room personnel evaluated by micronucleus test.

J Anesthesiol Clin Sci. 2013; 2:26.

http://dx.doi.org/10.7243/2049-9752-2-26 